Rural Economic Technical Assistance Center (2003): Maytag Plant Closure: IMPLAN Economic Impact Analysis, Macomb, IL: Illinois Institute for Rural Affairs

Slaughter, Matthew J. (2004): Globalization and Employment by U.S. Multinationals: A Framework and Facts, in: Daily Tax Report, March 26, 2004

Sleigh, Steve/Almeida, Paul/Khan, Faraz (2004): Losing Altitude: Employment in the Aerospace Sector, in: Perspectives on Work, Vol. 7, No. 2, pp. IO-I2

\title{
The British Economy: A Growth and Employment Miracle? Andrew Glyn*
}

Since 1990 the UK economy has grown at 2.4 percent per year, compared to I.7 percent in the Eurozone. ${ }^{\mathrm{I}}$ The growth differential in favour of the British economy, previously regarded as the "sick man of Europe«, has even been increasing. Since 2000 the UK has grown twice as fast as the Eurozone's I.2 percent per year. As a result the UK labour market looks distinctly healthier than Europe's. Both the UK and Euroland had around ten percent unemployment in the early I990s. But UK unemployment has been around five percent since 200I whilst in Europe it has been has fluctuating around nine percent. In the UK around 73 percent of the working age population are in work, as compared to 65 percent in the EU-I5. Moreover provision of jobs in the UK has not been at the expense of improvements in productivity, the basic determinant of the long-term growth of living standards. Since 2000 labour productivity in the UK business sector has been growing about I.5 percent per year, around three times the rate of advance in Europe.

In one sense such comparisons are rather flattering to the UK. For the UK economy has not been doing outstandingly well. Rather Europe, and in particular the big countries of continental Europe, have been doing extremely badly. Further, inequality rose faster in the UK than in any other EU country since 1979. The ratio of incomes ten percent from the top of the distribution to ten percent from the bottom is around 4.6 in the UK as compared to three to 3.5 in Northern Europe. Even so, thirteen years with UK growth between I.8 percent and 4.4 percent, combined with comparatively low unemployment, must seem an enviable record to European countries struggling with stagnation. How has the UK done it?

There are two obvious explanations. Keynesians would argue that the UK, once freed from the straightjacket of the Exchange Rate Mechanism (ERM), has benefited from ex-

* Corpus Christi College, Oxford.

I All data in this note is from current issues of OECD Economic Outlook, Employment Outlook and other OECD Reports. 
pansionary macroeconomic policy whilst Europe has been labouring under the restrictive Maastricht criteria for budget deficits and European Central Bank (ECB) obsession with inflation. This has allowed aggregate demand to expand more rapidly in the UK, encouraging both employment and investment. A second explanation is that the UK has undergone a more thorough and earlier process of economic »reform ", particularly deregulation of the labour market, product markets and financial markets. This is believed to encourage a more vibrant "supply side" of the economy bringing faster growth and rising demand. What does the evidence show?

\section{The Demand Side}

A glance at the data for interest rates shows that more expansionary monetary policy cannot explain the better growth performance of the UK. Immediately after the UK left the ERM interest rates were lower than in Europe, but from 1995 on the short-term interest rate has been lower in the Eurozone than in the UK in every single year. Moreover since 2000 the inflation rate has tended to be higher in the Eurozone countries, which has reduced the real interest rate there. Thus in 2004 the short-term interest rate in the UK was 4.6 percent in the UK and 2.I percent in the Eurozone, whilst slightly higher inflation in Europe meant that real interest rates were 3.3 percent in the UK and zero in the Eurozone. Of course this comparison cannot show whether the ECB should not have done more by way of cutting interest rates, given the stagnationist tendencies in Europe. It does show, however, that the poorer growth and employment record in Europe than in Britain cannot be blamed on a more restrictive monetary policy.

The other arm of macroeconomic policy is fiscal policy - the balance between government spending and revenues. In the I990s the fiscal patterns in the UK and the Eurozone were rather similar. Very expansionary policies in the early I990s were followed by extended periods of consolidation. In fact the fiscal squeeze was stronger in the UK, with a six percent of GDP "structural deficit" in 1994 (that is after adjustment for temporary cyclical factors) being converted into a surplus of one percent in 2000. In the Eurozone the tightening was from a similar deficit in the early I990s but the budget never got to within one percent of balance.

The tighter fiscal squeeze in the UK in the I990s was followed by a major fiscal expansion in the period of the second Blair government as the government came under heavy political pressure to improve public services. The structural deficit rose to 3.5 percent of GDP in 2004. In the Eurozone there was no significant further increase in the deficit after 2000. Thus even though fiscal policy looks of secondary importance in explaining growth differentials over the whole period, since 2000 the more expansionary fiscal policy in the UK definitely played a role in the considerably faster growth in the UK. We will return to the important role of government spending in sustaining UK growth after 2000 after briefly examining the »supply side» of the equation. 


\section{Supply Side Flexibility}

Over the period 1978 to 1998 , according to the OECD, the UK undertook more product market deregulation (including privatisation and reducing barriers to entry into markets) than any other OECD country, and in 2003 it had the least product market regulation of all the European countries. A ranking of freedom in capital markets showed the UK moving from the seventh place in the OECD in 1980 to the first place in 1998. Finally, the assault on labour market regulations and protection under Mrs Thatcher and her successors has resulted in the UK having the most unregulated and un-supported labour market in Europe. In 2000 the UK ratio of unemployment benefits to post-tax income was the lowest in Europe (some 50 percent as compared to 70 percent in Germany for example). UK employment protection was the lowest in Europe. Although union membership, at around 30 percent of employees, was still higher in the UK than in France, Spain and Germany, the coverage of collective bargaining arrangements was only 30 percent of employees, well under half the coverage rate typical in Europe. At first sight, then, the supply side offers a more plausible explanation of the UK's superior performance than do monetary and fiscal policy differences with Europe. This is not mainly Tony Blair's creation; the bulk of deregulation occurred under his conservative predecessors, though generally he has extended the process rather than trying to reverse it.

The impact of deregulation and reform on economic performance is hugely contentious. Perhaps the least contentious is the idea that greater competition may force firms to rationalise and invest in new technology, which is a strong thread in classical economics from Adam Smith through Karl Marx to Joseph Schumpeter. Of course whilst monopoly positions can stifle dynamism, opening them up to the pressure of competition is far from costless as workers may lose well paid jobs in the industries affected and become dependent on a more or less flexible labour market. So what is the evidence that lightly regulated labour markets like that of the UK generate superior performance in terms of jobs?

Despite the fact that the OECD, the IMF and other international organisations have been consistently pushing for labour market deregulation, at least since the early I990s, the evidence that high unemployment benefits or strong employment protection or high minimum wages is responsible for low employment is very weak. As Baker et al. (2005) show if you compare unemployment rates across OECD countries with the generosity of unemployment benefits or the strength of employment protection there is no correlation at all. Countries have reached low unemployment with both low benefits or high benefits. The same is true for employment protection or minimum wages. As this study shows the more sophisticated statistical analyses, which include a range of labour market measures and other influences on employment, do not give consistent or "robust « results for the role of benefits etc. Labour market deregulation has very uncertain effects on unemployment and certainly is not a necessary condition for high employment rates, since countries like Sweden and the Netherlands have achieved very high employment combined with comparatively generous social protection. 
Thus whilst the UK economy is certainly very deregulated this does not prove that the resulting "flexibility" is the cause of high employment. Before trying to draw a firmer conclusion, however, we need to examine some more features of the UK economy.

\section{Consumption, Exports and Government Spending}

An obvious explanation for fast growth in the UK is that British consumers have been much more willing to go out and borrow to spend as compared to more cautious consumers in Europe. It is true that the savings ratio (proportion of household income saved) is a good deal lower in the UK; at around six percent it compares with savings at about double this rate in the big European economies. But the main explanation for faster growth of consumption is faster growth of incomes, not falling savings ratio or rising borrowing. Just in one year, 1998, a decline in savings in the UK gave a once and for all boost to consumption and staved off an incipient slowdown. This was hardly fundamental however.

If the UK was really such a vibrant and competitive economy one would expect a rapid expansion of exports. Indeed the effective depreciation of sterling in the early I990s did generate quite an export boom that helped launch the expansion. Latterly, however, UK exports have stagnated - between 2000 and 2004 export growth in the UK was at about half the rate of allegedly sclerotic Germany. The competitiveness of UK manufacturing declined drastically in the later I990s as sterling appreciated and pushed up UK costs - the result was the overvalued exchange rate for sterling with which any recent visitor to the UK is all too familiar. The UK has had a balance of payments deficit of around two percent of GDP since the late I990s, contrasting with balance for the Eurozone. Indeed the deficit would have been much greater but for falling prices for imports, from China for example. UK manufacturing has a growing deficit, partially offset by export success in certain knowledge-based services (finance, consulting etc). Clearly international competitiveness and growing exports do not explain the UK's success.

We noted earlier that a strong fiscal expansion has helped the UK economy keep growing since 2000. Indeed this understates the recent impact of government spending. In the three years up to 2000 private sector employment went up just over 900,000; in the four years after 2000 the increase was only 300,000 . Moreover, this slowdown took place while the government was creating more work for private companies through the substantial increase in public spending.

Since 2000 the government has commissioned construction companies to build new hospitals and schools, spent more on drugs and schoolbooks and employed more catering, cleaning and other private service contractors. Such expenditure has been expanding faster than the public sector's own direct wage bill. Translating this rise in spending into jobs suggests that over the three years 2000 to 2003 , some half a million extra private sector jobs were created as a direct result of public spending. So government spending, as well as creating nearly half a million jobs in the public sector since 2000 , has been responsible for all recent growth in private sector employment. Thus rising government spending has been directly responsible for all the growth in UK employment since 2000. 
Of course we do not know what would have happened to employment after 2000 without the expansion of public spending. However, the experience of the last four or five years certainly does not support the idea that the UK's recent jobs growth has been the creation of a deregulated and vibrant private sector. A good old-fashioned Keynesian expansion seems much closer to the mark.

There is still one puzzle however. Even if it is granted that rising government spending has been the main motor behind the continued expansion in the UK, why has this not led to an upsurge of inflation? In the mid I990s leading economists were estimating that "structural unemployment " (the unemployment rate below which inflation would take off) in the UK was eight to nine percent and yet subsequently inflation has stayed low despite unemployment falling to five percent. If structural unemployment really has fallen like this and if the explanation is deregulation then deregulation would indeed be the fundamental factor explaining the fall in UK unemployment, even if the rise in government spending was also necessary to provide the necessary demand impetus in the economy.

Some people on the left denounce the concept of "structural unemployment « as a reactionary concept designed to pin the blame for mass unemployment on workers and justify labour market deregulation. Whilst it is often used in this way fundamentally the concept is the same as Marx's "reserve army of labour « - the slack in the labour market necessary to hold down wages to levels consistent with capital accumulation. So why has the reserve army fallen in the UK? Recently greater intensity of competition in product markets is often cited as "keeping the lid" on wage increases as employers face more intense competition from overseas. This would seem to apply equally in Europe, although the overvaluation of sterling has brought additional pressure on UK firms in recent years. The Bank of England has also mentioned the rapid inflow of workers from overseas into the UK, many from Europe, as an additional factor keeping the labour market less tight than the unemployment statistics would suggest. But again this hardly seems a trend specific to the UK.

The factor which most marks out the UK was Mrs Thatcher's assault on trade unions, culminating in the defeat of the miners' strikes. Tony Blair, whilst making a few minor concessions to the trades unions, has conspicuously failed to reverse most of the conservative policies to weaken unions and has definitely privileged the interests of business. This is not to accept the argument of the deregulators that reducing unemployment benefit or employment protection will generate more jobs. But in a capitalist economy, distributional conflict between capital and labour is always an issue and a radical weakening of labour is one way of keeping that conflict in check without requiring mass unemployment. The big countries of continental Europe, unlike some of their smaller North European neighbours, have for complex reasons connected with their institutions and history, failed to find an alternative corporatist solution. Employers and government have not, yet, followed the risky, Thatcherite route of a decisive showdown with labour. It is presumably fear of re-igniting the old wage price spiral which keeps the ECB from the kind of aggressive interest rate cutting in the face of demand weakness that has characterised Alan Greenspan's period as Chairman of the US Fed. The Bank of England did not need to do this in the years after 2000 as government expansion was keeping the economy moving. 
The UK economy looks to be at a turning point with unemployment on the rise. Growth is faltering as the government thrust to demand is weakening and all the talk is of the housing market declines, continued feeble business investment and the worst consumer sales figures for 20 years. There is no sign whatever that a vibrant, deregulated private sector is about to take up the slack. The days of Tony Blair and Chancellor Gordon Brown preaching smugly to their European counterparts about the virtues of flexibility may be numbered.

\section{Reference}

Baker, Dean/Glyn, Andrew/Howell, David/Schmitt, John (2005): Labour Market Institutions and Unemployment: A Critical Assessment of the Cross-country Evidence, in: Howell, David (ed.), Fighting Unemployment. The Limits of Free Market Orthodoxy, Oxford University Press: New York, pp. 72-II8

\section{Noch eine Reform: Der neue Tarifvertrag im öffentlichen Dienst Consuela Ramos*}

Ohne Zweifel: Die Bundesrepublik Deutschland befindet sich im »Reformfieber«. Die Diskussion um angeblich notwendige Veränderungen der ökonomischen und sozialen Institutionen Deutschlands ist zu einem Macht generierenden Diskurs geworden. Politische Akteur|inn|e|n müssen sich als »reformfähig « darstellen, um überhaupt noch in der Öffentlichkeit wahrgenommen zu werden oder gar Einfluss auf die konkrete Ausgestaltung von Veränderungen nehmen zu können.

Im Februar dieses Jahres bewiesen die Tarifpartner|innen des öffentlichen Dienstes, an ihrer Spitze Innenminister Otto Schily und der Vorsitzende der Vereinten Dienstleistungs-

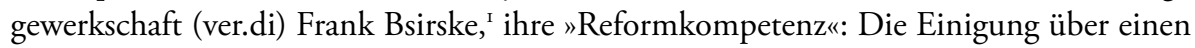
neuen Tarifvertrag für die Beschäftigten des Bundes und der Kommunen - die Länder wehren sich derzeit noch gegen die Übernahme des Ergebnisses - wurde von Bsirske als "Jahrhundert-Reform «" gefeiert. Die meisten Kommentator|inn|en waren nicht ganz so

* Göttingen.

I Wichtige weitere Tarifparteien in den Verhandlungen um den Tarifvertrag für den öffentlichen Dienst (TVöD) waren auf Seite der Beschäftigten die dbb tarifunion, auf Seite der Verwaltungen die kommunalen Arbeitgeberverbände. Die dbb tarifunion führt die Tarifverhandlungen für Fachgewerkschaften und Berufsverbände des öffentlichen Dienstes und seiner privatisierten Bereiche.

2 Frankfurter Allgemeine Zeitung vom I0.02.2005. 